\title{
GENERALIZATION OF MAJORIZATION THEOREM
}

\author{
M. AdiL KHAN, N. LATIF AND J. PEČARIĆ
}

\begin{abstract}
We give generalization of majorization theorem for the class of $n$-convex functions by using Taylor's formula and Green function. We use inequalities for the Čebyšev functional to obtain bounds for the identities related to generalizations of majorization inequalities. We present mean value theorems and $n$-exponential convexity for the functional obtained from the generalized majorization inequalities. At the end we discuss the results for particular families of function and give means.
\end{abstract}

Mathematics subject classification (2010): 26D15, 26D20, 26D99.

Keywords and phrases: Majorization theorem, Taylor's formula, Cebysev functional, $n$-exponentially convex function, Stolarsky type means.

\section{REFERENCES}

[1] M. Adil Khan, Naveed Latif, I. Perić and J. PeČArić, On Sapogov's extension of Čebyšev's inequality, Thai J. Math., 10 (2) (2012), 617-633.

[2] M. Adil Khan, Naveed Latif, I. Perić And J. PeČarić, On majorization for matrices, Math. Balkanica, to appear.

[3] M. Adil Khan, M. NiEZgoda And J. PeČARIĆ, On a refinement of the majorization type inequality, Demonstratio Math., 44 (1) (2011), 49-57.

[4] M. Adil Khan, Sadia Khalid And J. PeČArić, Refinements of some majorization type inequalities, J. Math. Inequal., 7 (1) (2013), 73-92.

[5] N. S. Barnett, P. Cerone, S. S. Dragomir, Majorisation inequalities for Stieltjes integrals, Appl. Math. Lett., 22 (2009), 416-421.

[6] S. N. Bernstein, Sur les fonctions absolument monotones, Acta Math. 52 (1929), 1-66.

[7] P. Cerone, S. S. Dragomir, Some new Ostrowski-type bounds for the Čebyšev functional and applications, J. Math. Inequal. 8 (1) (2014), 159-170.

[8] L. Fuchs, A new proof of an inequality of Hardy-Littlewood-Polya, Mat. Tidsskr, B (1947), 53-54.

[9] J. JAKŠETIĆ, J. PEČARIĆ, Exponential convexity method, J. Convex Anal. (2013), no. 1, 181-197.

[10] J. JAKŠETIĆ, J. PEČARIĆ, A. PERUŠIĆ, Steffensen inequality, higher order convexity and exponential convexity, Rend. Circ. Mat. Palermo 63 (1) (2014), 109-127.

[11] N. Latif, J. PeČarić And I. Perić, On Majorization, Favard and Berwald's Inequalities, Annals of Functional Analysis, 2 (2011), no. 1, 31-50, ISSN: 2008-8752.

[12] L. Maligranda, J. PeČArić, L. E. Persson, Weighted Favard's and Berwald's Inequalities, J. Math. Anal. Appl. 190 (1995), 248-262.

[13] A. W. Marshall, I. Olkin ANd BARry C. ARnold, Inequalities: Theory of Majorization and Its Applications (Second Edition), Springer Series in Statistics, New York 2011.

[14] M. NiEZGodA, Remarks on convex functions and separable sequences, Discrete Math. 308 (2008), $1765-1773$.

[15] J. Pečarić, F. Proschan And Y. L. Tong, Convex functions, Partial Orderings and Statistical Applications, Academic Press, New York, 1992.

[16] J. PEČARIĆ, J. PERIĆ, Improvements of the Giaccardi and the Petrović inequality and related results, An. Univ. Craiova Ser. Mat. Inform., 39 (1) (2012), 65-75.

[17] J. PEČARIĆ, On some inequalities for functions with nondecreasing increments, J. Math. Anal. Appl., 98 (1984), 188-197. 
[18] D. V. WiddeR, The Laplace Transform, Princeton Univ. Press, New Jersey, 1941.

[19] D. V. Widder, Completely convex function and Lidstone series, Trans. Am. Math. Soc. 51 (1942), 387-398. 